\title{
Dietary L-Tryptophan Modulates the
} Hematological Immune and Antibacterial Ability of the Chinese Mitten Crab, Eriocheir sinensis, Under Cheliped Autotomy Stress

\author{
Cong Zhang 1,2,3, Qian Zhang 1,2,3, Xiaozhe Song 1,2,3, Yangyang Pang ${ }^{1,2,3}$, Yameng Song 1,2, , \\ Yongxu Cheng ${ }^{1,2,3 *}$ and Xiaozhen Yang ${ }^{1,2,3 *}$
}

${ }^{1}$ Demonstration Center for Experimental Fisheries Science Education, Shanghai Ocean University, Shanghai, China, ${ }^{2}$ Key Laboratory of Freshwater Aquatic Genetic Resources, Ministry of Agriculture, Shanghai Ocean University, Shanghai, China,

${ }^{3}$ National Engineering Research Center of Aquaculture, Shanghai Ocean University, Shanghai, China

OPEN ACCESS

Edited by:

Emilio Jirillo,

Università degli Studi di Bari, Italy

Reviewed by:

Erling Olaf Koppang,

Norwegian University of Life Sciences,

Norway

Aldo Corriero,

Università degli Studi di Bari, Italy

*Correspondence:

Yongxu Cheng

chengyongxucrablab@hotmail.com

Xiaozhen Yang

zny119@163.com;

xzyang@shou.edu.cn

Specialty section

This article was submitted to Nutritional Immunology,

a section of the journal

Frontiers in Immunology

Received: 23 July 2018 Accepted: 07 November 2018 Published: 06 December 2018

Citation:

Zhang C, Zhang Q, Song X, Pang Y, Song $Y$, Cheng $Y$ and Yang $X$ (2018) Dietary L-Tryptophan Modulates the

Hematological Immune and

Antibacterial Ability of the Chinese Mitten Crab, Eriocheir sinensis, Under

Cheliped Autotomy Stress.

Front. Immunol. 9:2744.

doi: 10.3389/fimmu.2018.02744
In pond cultures of juvenile Eriocheir sinensis, limb autotomy stress seriously affects and restricts the quality and economic benefits of aquaculture. This study was designed to evaluate the effects of dietary supplementation of L-tryptophan on $E$. sinensis under the cheliped autotomy stress. In the present study, 252 crabs were divided into four groups: dietary L-trp supplementation with $0.28,0.40,0.53$, and $0.70 \%$, and their hematological immunity, antioxidant capacity, anti-stress, and antibacterial ability were evaluated after 14 days of using biochemical analysis, flow cytometry, and molecular biology techniques. First, we counted the mortality after 14 days of feeding and found that compared with other treatments, dietary supplementation of 0.53 and $0.70 \%$ L-trp significantly lowered the mortality of $E$. sinensis. Moreover, the total hemocyte count (THC), hemocyanin, and glutathione (GSH) content, and glutathione peroxidase (GSH-Px) activity significantly increased at 7 and $14 \mathrm{~d}$ with dietary supplementation of 0.53 and $0.70 \% \mathrm{~L}$-trp, in contrast with the significant decrease in malondialdehyde (MDA) content at $14 \mathrm{~d}$ in the same dietary groups $(P<0.05)$. Next, the bacterial challenge test after 14 days of feeding showed that the THC levels, phagocytic rate, and acid phosphatase (ACP) and alkaline phosphatase (ALP) activity were significantly higher with dietary supplementation of 0.53 and $0.70 \%$ L-trp after 12 and $24 \mathrm{~h}$ of Aeromonas hydrophila injection, along with a significant improvement in the antioxidant capacity $(P<0.05)$. Further, we measured the expression of antibacterial-related protein genes (EslecB and HSP 90) and found that they were significant up-regulated in the hepatopancreas, hemocytes, intestine, and gill in the groups with dietary supplementation of $0.53 \%$ and $0.70 \%$ L-trp after $12 \mathrm{~h}$ or $24 \mathrm{~h}$ of $A$. hydrophila injection $(P<0.05)$. Taken together, the observations in this study indicate that dietary supplementation of L-trp can enhance the antioxidant capacity and improve the hematological immune status and antibacterial ability of $E$. sinensis under the cheliped autotomy stress, thereby increasing the survival rate of $E$. sinensis under cheliped autotomy stress.

Keywords: Eriocheir sinensis, autotomy cheliped, L-tryptophan, hematological immune, antioxidant capacity 


\section{INTRODUCTION}

The Chinese mitten crab, Eriocheir sinensis, occupies an important position in China's aquaculture industry, owing to its rich nutritional value and wide market demand. However, in pond cultures of E. sinensis, various factors, such as fighting, defense, and foraging, can cause a high rate of limb autotomy, (1-4). Limb autotomy has many adverse effects on the crabs, including long-term loss of function and energy (5), as well as, decreased feeding efficiency and survival rate $(6,7)$. Moreover, limb autotomy reduces the ability of immune defense to resist pathogens (8). Zhao et al. reported that coin-sized crabs have up to $30 \%$ limb autotomy rate in earthen pond culture conditions of E. sinensis (9). The problem of limb autotomy stress has seriously affected and restricted the quality and aquaculture economic benefits of $E$. sinensis, resulting in widespread concern $(8,10,11)$.

Several studies have shown that nutritional adjustment can regulate the immune system of aquatic animals and is one of the effective means to enhance anti-stress ability $(12,13)$. As an important part of animal diet, amino acids play an important role in the growth and immune regulation of aquatic animals $(12,14)$. Among them, tryptophan as an essential amino acid can improve the inflammation response (15), which can be used as feed grade at present. Studies have reported that dietary supplementation with tryptophan can modulate intestinal immune response and antioxidant status in Ctenopharyngodon Idella (16) and regulate the non-specific immune response in Apostichopus japonicus Selenka (17), which play an important role in immune regulation and anti-stress responses in aquatic animals.

At present, agricultural activities have changed the natural balance between pairs of original hosts and their pathogens, which could lead to the emergence of diseases and other serious problems for the aquaculture industry $(15,18)$. Pathogenic Aeromonas hydrophila can cause serious diseases such as "Tremble Disease" and "Edema Disease" in E. sinensis (19). Therefore, A. hydrophila can be used as an experimental infection bacterium to evaluate the antibacterial ability of $E$. sinensis.

Crustaceans lack acquired immune system and their immune system mainly includes hematological and cellular immunity. Hematological immunity further includes some humoral immune factors present in the hemolymph, such as heat shock proteins 90 (HSP 90) (20), C-type lectin (21), hemocyanin (22), and some immune-related enzymes such as hydrolases (23) and, antioxidant enzymes (24). Hemocyte immunity mainly includes phagocytosis, package action, agglutination, and melanization of hemocytes (25). In invertebrates, hemocyte phagocytosis is widely used to assess their antibacterial ability (26). When invertebrates are attacked by pathogens, oxygen free radicals are released to enhance their antibacterial ability (27). In addition, hemocytes can adhere to pathogens, trigger phagocytosis, and produce highly toxic reactive oxygen species (ROS) (28). Our previous studies have shown that melatonin (N-acetyl-5-methoxytryptamine) can significantly improve the serum antioxidant capacity of E. sinensis (29). As the precursor of melatonin, tryptophan is an effective scavenger for free radicals and can maintain the cellular redox balance by enhancing the body's antioxidant capacity (30). Moreover, many studies have reported that hemocyanin, HSP 90, and C-type lectins EslecB play important roles in the anti-stress response and immune defense response against pathogen attacks (20-22).

Therefore, dietary supplementation of key amino acids is an effective means of improving animal immunity, which is a more cost-effective and safer solution than one involving adding antibiotics (12). However, to date, there is no report on the effects of dietary supplementation of L-trp on the anti-stress and antibacterial ability of E. sinensis. Therefore, this study was designed to evaluate the effects of dietary supplementation of L-trp on hematological immunity, antioxidant capacity, andantistress and antibacterial ability of E. sinensis, in order to provide some scientific guidance for improving the anti-stress and disease resistance of $E$. sinensis from a nutritional perspective.

\section{MATERIALS AND METHODS}

\section{Diets}

The composition and nutritional level of the basal diet is presented in Table 1. The main protein sources of feed were rapeseed meal, soybean meal and cotton meal, while the fat sources were pork lard, fish oil, and phosphatide oil. Based on studies on Scylla serrata and Astacus leptodactylus (31-33), the L-trp contents in the four experimental diets in this study were determined to be $0.28 \%$ (Diet \# A) (control), 0.40\% (Diet \# B), $0.53 \%$ (Diet \# C), and 0.70\% (Diet \# D), respectively. L-trp ( $\geq 99.7 \%$ ) was purchased from Sinopharm Chemical Reagent Co., Ltd (China). Ingredients were ground into fine powder through a $187.5 \mu \mathrm{m}$ mesh sieve. Then weigh accurately, using a step-by-step expansion method to add trace L-tryptophan, mix evenly, and use a double screw extruder to make pellet feed at $1.5 \mathrm{~mm}$ diameter. Then spread out and dried in an oven at $55^{\circ} \mathrm{C}$. After cooling under natural conditions, it was stored in a ziplock bag and stored in a refrigerator at $-20^{\circ} \mathrm{C}$. The actual content of L-trp in different diets was determined by reversed-phase high-performance liquid chromatography (RP-HPLC). A C18 ( $\mu$-Bondapak Cl8 column, diameter $25 \mathrm{~cm} \times 4.6 \mathrm{~mm}$ ) column was selected, the mobile phase was composed of sodium acetate buffer + methanol $=95+5$, the flow rate was $1.5 \mathrm{~mL} / \mathrm{min}$, ultraviolet (UV) detection wavelength was $280 \mathrm{~nm}$, the injection volume was $15 \mu \mathrm{L}$, and the column was at room temperature.

\section{Experimental Crabs}

All experimental protocols were reviewed and approved by the Animal Bioethics Committee, Shanghai Ocean University, China. In May 2018, 350 hard-shelled crabs that had just finished molting and limb-intact E. sinensis (Crustacea; Decapoda; Grapsidae) juvenile crabs $(16.89 \pm 3.87 \mathrm{~g})$, were collected from an earth pond at the Chongming research base of Shanghai Ocean University (Shanghai, China). Juvenile crabs were acclimated in 24-L ultra-clear glass tanks, each of which was supplied with continuous aerated freshwater at $24-28^{\circ} \mathrm{C}, \mathrm{pH} 7.84 \pm 0.08$, DO concentration $6.3 \pm 0.4 \mathrm{mg} / \mathrm{L}$, salinity $0.3 \%$, total ammonia 0.36 $\pm 0.03 \mathrm{mg} / \mathrm{L}$, chloride level $136 \pm 15 \mathrm{mg} / \mathrm{L}$, and basal nitrite $<0.05 \mathrm{mg} / \mathrm{L}^{-1}$ and natural photoperiod conditioning for 1 week. The crabs were fed once a day with a commercial crab diet (Diet \# A). 
TABLE 1 | Ingredients and proximate composition of the control diets (\% dry matter).

\begin{tabular}{|c|c|}
\hline Ingredient & Content \\
\hline Soybean meal & 15.50 \\
\hline Peanut meal & 8.00 \\
\hline Rapeseed meal & 18.00 \\
\hline Cotton meal & 7.00 \\
\hline Fish meal & 7.00 \\
\hline Wheat flour & 28.30 \\
\hline Yeast meal & 2.00 \\
\hline Squid powder & 2.00 \\
\hline Phosphatide oil & 2.00 \\
\hline Fish oil & 1.50 \\
\hline Pork lard & 1.50 \\
\hline Mineral mix ${ }^{a}$ & 0.30 \\
\hline Vitamin mix ${ }^{b}$ & 1.20 \\
\hline $\mathrm{Ca}\left(\mathrm{H}_{2} \mathrm{PO}_{4}\right)_{2}$ & 1.00 \\
\hline Choline chloride & 0.40 \\
\hline Dishulin & 0.10 \\
\hline Bentonite & 4.00 \\
\hline Salt & 0.20 \\
\hline Total & 100.00 \\
\hline \multicolumn{2}{|c|}{ ANALYZED COMPOSITION } \\
\hline Moisture & 11.45 \\
\hline Crude protein & 34.56 \\
\hline Crude lipid & 8.34 \\
\hline Ash & 9.15 \\
\hline
\end{tabular}

a Vitamin premix (per $\mathrm{kg}$ diet): vitamin A, $62500 \mathrm{U}$; vitamin $D_{3}, 15000 \mathrm{U}$; vitamin $E$, $1.75 \mathrm{~g}$; vitamin $K_{3}, 35.4 \mathrm{mg}$; vitamin $B_{1}, 100 \mathrm{mg}$; vitamin $B_{2}, 150 \mathrm{mg}$; vitamin $B_{6}, 150 \mathrm{mg}$; vitamin $B_{12}, 0.2 \mathrm{mg}$; biotin, $4 \mathrm{mg}$; D-calcium pantothenate, $250 \mathrm{mg}$; folic acid, $25 \mathrm{mg}$; nicotinamide, $300 \mathrm{mg}$; vitamin C, $700 \mathrm{mg}$.

${ }^{b}$ Mineral premix (per kg diet): $\mathrm{FeSO}_{4} \cdot \mathrm{H}_{2} \mathrm{O}, 200 \mathrm{mg}$; $\mathrm{CuSO}_{4} \cdot{ }_{5} \mathrm{H}_{2} \mathrm{O}, 96 \mathrm{mg} ; \mathrm{ZnSO}_{4} \cdot \mathrm{H}_{2} \mathrm{O}$, $360 \mathrm{mg} ; \mathrm{MnSO}_{4} \cdot \mathrm{H}_{2} \mathrm{O}, 120 \mathrm{mg} ; \mathrm{MgSO}_{4} \cdot \mathrm{H}_{2} \mathrm{O}, 240 \mathrm{mg} ; \mathrm{KH}_{2} \mathrm{PO}_{4}, 4.2 \mathrm{~g} ; \mathrm{NaH}_{2} \mathrm{PO}_{4}, 0.5 \mathrm{~g}$; $\mathrm{Kl}, 5.4 \mathrm{mg} ; \mathrm{CoCl}_{2} \cdot{ }_{6} \mathrm{H}_{2} \mathrm{O}, 2.1 \mathrm{mg} ; \mathrm{Na}_{2} \mathrm{SeO}_{3}, 3 \mathrm{mg}$.

\section{Experimental Design}

The experimental design and sampling procedures are shown in Figure 1. A total of 252 limb-intact crabs were selected from the above samples and subjected to induction for autotomy of the left cheliped. For this, the researchers gently grasped the limbs of the crabs using their fingers, and the crab would spontaneously autotomize the corresponding limbs. Next, all the autotomized crabs were randomly divided into four groups: Diet \# A, Diet \# B, Diet \# C, and Diet \# D. Each diet group had three replicates. The crabs were returned to the aerated water in monoculture systems immediately afterwards, and maintained under the environmental conditions described above.

\section{Trial 1: Feeding Trial}

A previous study had reported that 14 days of feeding on diets supplemented with individual amino acids are enough to modulate physiological and immune responses in aquatic animal (34). The feeding trial in this study lasted for 2 weeks, with an aim to evaluate the effects of short-term dietary supplementation with L-trp on cellular and hematological immune status. The mortality of all groups was calculated at the end of the experiment. Hemolymph were collected at 1,7 , and $14 \mathrm{~d}$, respectively, since the start of the experiment. Hemolymph was drawn using a sterile 1-ml syringe from the unsclerotized membrane of the right third periopod and was diluted 1:1 with steriled anticoagulation mixture (trisodium citrate $30 \mathrm{mM}, \mathrm{NaCl}$ $338 \mathrm{mM}$, glucose $115 \mathrm{mM}$, EDTA $10 \mathrm{mM}$ ). The mixture was centrifugated at $42,000 \times \mathrm{g}$ for $5 \mathrm{~min}$ to separate the serum and the hemocytes, and then stored at $-20^{\circ} \mathrm{C}$ for evaluation of THC levels, hemocyanin content and antioxidant capacity.

\section{Trial 2: Bacterial Challenge Test}

This experiment was designed to investigate the effect of L-trp supplementation on the antibacterial ability and immunomodulation after bacterial infection of $E$. sinensis. At the end of the Trial 1 (after 14 days of feeding), the bacterial challenge test was carried out. Frozen sample of Aeromonas hydrophila was obtained from Shanghai Ocean University (8). The cultured bacteria were resuspended in crustacean saline $\left(\mathrm{NaCl} 0.21 \mathrm{M}, \mathrm{KCl} 13.6 \mathrm{mM}, \mathrm{H}_{3} \mathrm{BO}_{3} 8.6 \mathrm{mM}, \mathrm{NaOH} 4.75 \mathrm{mM}\right.$, $\mathrm{MgSO}_{4} \mathrm{j}_{7} \mathrm{H}_{2} \mathrm{O} 20 \mathrm{mM}, \mathrm{pH} 7.2$ ), and the concentration of the suspension was adjusted to $4 \times 10^{5} \mathrm{CFU} / \mathrm{mL}$ (the Median lethal concentration $\left(\mathrm{LC}_{50}\right)$ obtained from pre-experimental analysis) (8). Each crab was injected with $100 \mu \mathrm{L}$ bacterial suspension. Crabs were sampled for hepatopancreas, hemolymph, gill and intestine collection at 12 and $24 \mathrm{~h}$ after A. hydrophila injection. Hemolymph was collected and centrifuged as described above, and the serum and hemocytes were then collected separately for further experimental analysis.

\section{Hemolymph Samples Analysis Hemocyte Level of THC}

The levels of THC were obtained with a drop of the anticoagulant hemolymph placed in a hemocytometer using a Leica DMIL microscope (Leica Microsystems GmbH, Wetzlar, Germany) and each crab count was repeated three times.

\section{Immune-Related Parameters}

Hemocyanin concentrations were determined by a UVSpectrophotometric (Beijing Purkinje General Instrument Co., Ltd) at $335 \mathrm{~nm}$ with $10 \mu \mathrm{L}$ of serum diluted in $990 \mu \mathrm{L}$ distilled water in a quartz cuvette, manually calibrated with distilled water. Hemocyanin concentrations $(\mathrm{mmol} / \mathrm{L})=2.69 \mathrm{E}(1 \%$, $1 \mathrm{~cm}) \mathrm{mmol} / \mathrm{L}(35)$.

The acid phosphatase (ACP), alkaline phosphatase (ALP) were measured by a UV-spectrophotometer (Beijing Purkinje General Instrument Co., Ltd) at $520 \mathrm{~nm}$ with corresponding detection kits (Nanjing Jiancheng Bioengineering Institute, Nanjing, China) according to the manufacturer's protocols.

\section{Anti-oxidant Defense Systems Parameters}

Commercial kits obtained for SOD, GSH, GSH-Px, and MDA from Nanjing Jiancheng Bioengineering Institute (Nanjing, China) were used to measure their activities in the hemolymph supernatant. They were measured using a UV-spectrophotometer (Beijing Purkinje General Instrument 
Co., Ltd) at 520, 420, 412, and $532 \mathrm{~nm}$ as described by the manufacturer's protocols, respectively.

\section{Hemocyte Phagocytosis}

The hemocyte phagocytosis was analyzed by using a BD Accuri $^{\mathrm{TM}}$ C6 flow cytometer (BD Biosciences, USA). In trial 2, the hemocyte collected after centrifugation were resuspended in 0.1 M PBS buffer ( $\mathrm{NaCl} 136.89 \mathrm{mM} ; \mathrm{KCl} 2.67 \mathrm{mM} ; \mathrm{Na}_{2} \mathrm{HPO}_{4}$ $8.10 \mathrm{mM} ; \quad \mathrm{KH}_{2} \mathrm{PO}_{4} 76 \mathrm{mM} ; \mathrm{pH} 7.2-7.4$ ) (Sangon Biotech Co., Ltd., Shanghai, China). Thirty microliter fluorescent microspheres mother liquor (FluoSpheres ${ }^{\mathrm{TM}}$ CarboxylateModified Microspheres, $1.0 \mu \mathrm{m}$, red fluorescent, 580/605, F881, Invitrogen) were added to $1.5 \mathrm{ml}$ of PBS buffer and mixed to prepare a fluorescent microspheres suspension. Transfer 200 $\mu \mathrm{l}$ of blood cell suspension into $1.5 \mathrm{ml} \mathrm{EP}$ tube, add $50 \mu \mathrm{l}$ of fluorescent microspheres suspension, mix well, and avoid light reaction at $18^{\circ} \mathrm{C}$ for $1 \mathrm{~h}$. The reaction was stopped by the addition of $250 \mu \mathrm{l}$ of Baker's formol fixative (4\% formaldehyde, $2 \% \mathrm{NaCl}$ ) and then sequentially determined by flow cytometry. Each sample analysis included a total of 2,00,00 events and the flow speed was maintained at $<300 \mathrm{~s}^{-1}$. Phagocytosis was defined as the proportion of hemocytes that had ingested at least three fluorescent beads. The data were analyzed by using the $\mathrm{BD}$ CellQuest $^{\mathrm{TM}}$ Pro software (BD Biosciences, USA).

\section{Expression of the HSP 90 Gene Level: Quantitative RT-PCR}

Total RNA was extracted from the hemocyte, hepatopancreas intestinal and gill tissues using RNAiso $^{\text {TM }}$ plus reagent (RNA Extraction Kit, TaKaRa, Japan) according to the manufacturer's protocol. The concentration and quality of the total RNA were estimated by micro-volume ultravioletvisible spectrophotometer (Quawell Q5000; Thmorgan, China) and agarose-gel electrophoresis, respectively, and reverse transcribed with the PrimeScript ${ }^{\mathrm{TM}}$ RT reagent Kit (Perfect Real Time, TaKaRa, Japan) according to the manufacturer's protocol. The obtained cDNA that was diluted to 1:2 with double-distilled water was used as qRT-PCR template. Relative quantification was performed using the ABI 7,500 Real-Time PCR System (Life Technology, USA) with a ChamQ ${ }^{\mathrm{TM}}$ Universal SYBR ${ }^{\circledR}$ qPCR Master Mix (Vazyme Biotech Co.,Ltd, Nanjing, China) kits using the following program: $95^{\circ} \mathrm{C}$ for $30 \mathrm{~s} ; 40$ cycles at $95^{\circ} \mathrm{C}$ for $5 \mathrm{~s}$, $60^{\circ} \mathrm{C}$ for $34 \mathrm{~s}$; followed by a melting curve at $95^{\circ} \mathrm{C}$ for $15 \mathrm{~s}, 60^{\circ} \mathrm{C}$ for $1 \mathrm{~min}, 95^{\circ} \mathrm{C}$ for $15 \mathrm{~s}$. The PCR primer sequences for HSP 90 is shown in Table 2 (Sangon Biotech Co., Ltd., Shanghai, China). $\beta$-actin was used as the internal control and performed in triplicate for every sample. Relative changes in gene expression levels were determined by $2^{-\Delta \Delta C t}$ method. Data were analyzed and presented as average values \pm standard deviation (SD), as well as, the $\mathrm{n}$-fold difference relative to the control data.

\section{Statistical Analyses}

Data are presented as the average values of six individuals \pm standard deviation (SD) $(n=6)$, before the test, each sample was an independent individual and no pooling was carried out. The percentage values (dependent variable) were arcsine transformed before analysis. The effects of treatment were statistically analyzed using an analysis of variance (oneway ANOVA, LSD and Duncan analysis), and a $P<0.05$ was considered significant. All statistical analyses were performed using SPSS 20.0 software (Chicago, USA; Version 22.0).

\section{RESULTS}

\section{Mortality and Hemolymph Analysis After Dietary Supplementation of L-TRP For 14d Mortality}

At the end of the experiment at $14 \mathrm{~d}$, we evaluated the mortality of all groups as shown in Figure 2. The mortality of crabs in Diet \# C $(12.70 \pm 2.75 \%)$ and Diet \# D $(19.05 \pm 4.76 \%)$ groups were significantly lower than that in the control group (Diet \# A group) $(33.33 \pm 4.76 \%)(P<0.05)$. The mortality of Diet \# C group exhibited the lowest value among all other groups. The results

TABLE 2 | Primer information for quantitative real-time polymerase chain reaction.

\begin{tabular}{lll}
\hline Primers & Sequences $\left(\mathbf{5}^{\prime} \mathbf{-} \mathbf{3}^{\prime}\right)$ & Usage \\
\hline EsLecB- $F$ & GACAGGCATCAACGAGAAGGA & Real-time -PCR \\
EsLecB- $R$ & CACAGTTGTAATTATTGTATCCCG & Real-time -PCR \\
HSP $90-F$ & GAAGGTGATCCGCAAGAACC & Real-time -PCR \\
HSP $90-R$ & GTTGGTGGAGTCCTCATGGA & Real-time -PCR \\
$\beta$-actin $-F$ & TCATCACCATCGGCAATGA & Real-time -PCR \\
$\beta$-actin $-R$ & TTGTAAGTGGTCTCGTGGATG & Real-time -PCR
\end{tabular}

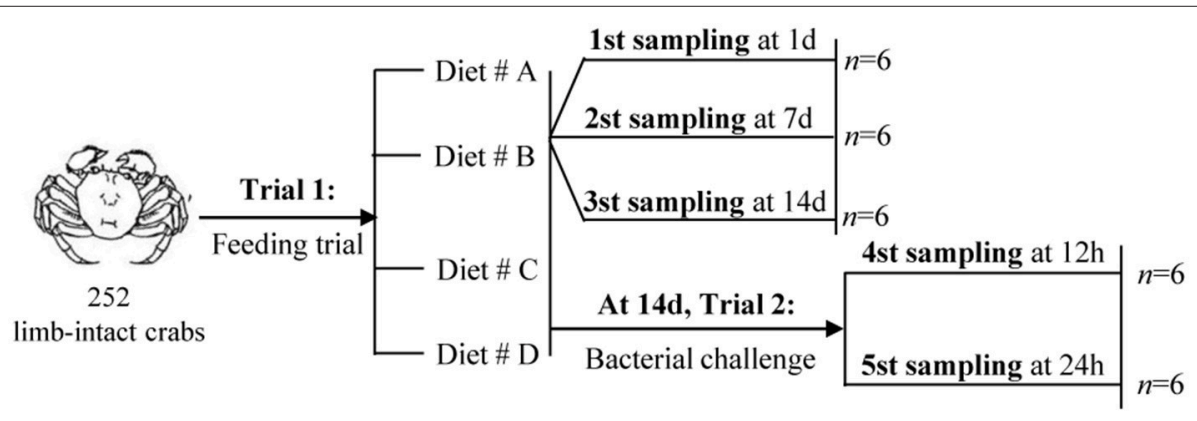

FIGURE 1 | The experimental design and sampling procedures. 


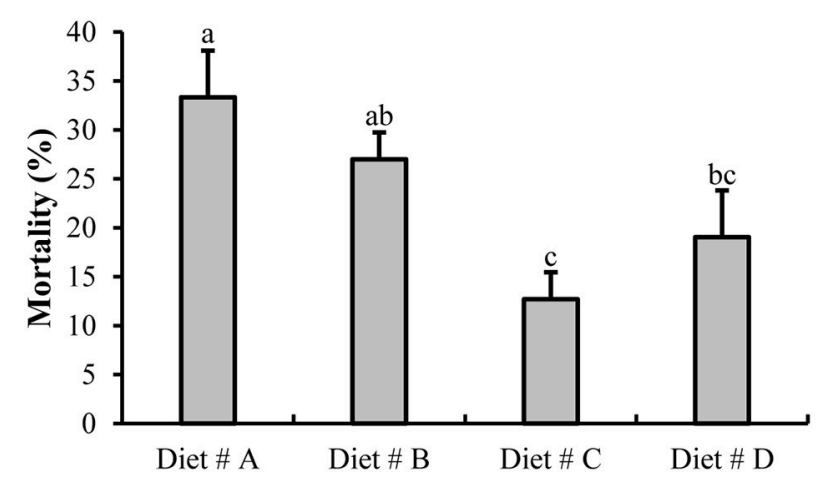

FIGURE 2 | The mortality of $E$. sinensis for all groups after fed dietary treatments at $14 \mathrm{~d}$. The values are expressed as the means $\pm \operatorname{SD}(n=21)$. Different letters placed above the column represent the significant differences $(P<0.05)$.

showed that dietary supplementation of L-trp can significantly reduce the mortality of $E$. sinensis.

\section{THC Levels and Hemocyanin Content}

There was no significant difference in the THC levels and hemocyanin content among the four dietary groups at $1 \mathrm{~d}$ after the start of the experiment (Figure 3). However, the THC levels were significantly higher in the L-trp supplement groups than in the Diet \# A group $(P<0.05)$ at 7 and $14 \mathrm{~d}$, whereas there the THC levels was no significant difference among between the three L-trp supplement groups (Figure 3A). The hemocyanin content in Diet \# C and Diet \# D groups was significantly higher than that in Diet \# A group at $7 \mathrm{~d}$ and $14 \mathrm{~d}(P<0.05)$, with the highest level observed in Diet \# C group (Figure 3B).

\section{Antioxidant Capacity}

There was no significant difference in SOD activity among the four diet groups (Table 3). The GSH contents were significantly higher in Diet \# C group at $7 \mathrm{~d}$ and in Diet \# D group at 14 $\mathrm{d}$ than in Diet \# A group $(P<0.05)$ (Table 3). The GSH-Px activity tended to gradually increase with the increased L-trp supplementation in diet, and it was significantly higher in Diet \# D than in other groups at $7 \mathrm{~d}(P<0.05)$ (Table 3). The MDA content was significantly lower in Diet \# C and Diet \# D groups than in Diet \# A group at $14 \mathrm{~d}(P<0.05)$ (Table 3$)$. The results showed that dietary supplementation of L-trp significantly enhanced the serum antioxidant capacity of E. sinensis.

\section{Bacterial Challenge Test Hematological Immune Status}

The THC levels in Diet \# C and Diet \# D group were significantly higher than those in the control group after 12 and $24 \mathrm{~h}$ of $A$. hydrophila injection $(P<0.05)$ (Figure 4A).

Some representative images of hemocyte phagocytosis obtained by flow cytometry are shown in Figures 5A-H. The phagocytic rate of hemocyte in Diet \# C and Diet \# D group was significantly higher than that in the control group after 12 and $24 \mathrm{~h}$ of $A$. hydrophila injection and a significant increased was

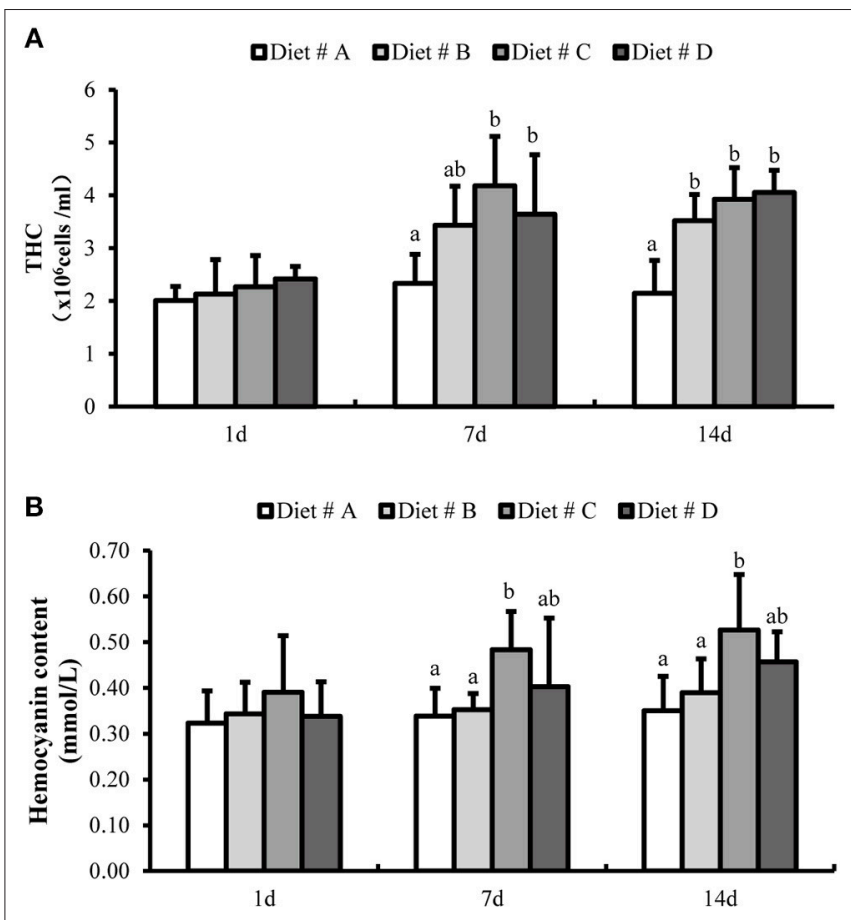

FIGURE 3 | The total hemocyte counts (THC) (A) and hemocyanin contents (B) in E. sinensis with different treatment at 1, 7, and $14 \mathrm{~d}$. The values are expressed as the means $\pm \mathrm{SD}(n=6)$. Different letters placed above the column represent the significant differences between different groups at the same time $(P<0.05)$.

observed at $24 \mathrm{~h}$ compared with $12 \mathrm{~h}$ after $A$. hydrophila injection in Diet \# B, Diet \# C and Diet \# D group $(P<0.01)$ (Figure 5I).

The hemocyanin content in Diet \# C group and Diet \# D group was significantly lower than that in the control group after 12 and $24 \mathrm{~h}$ of $A$. hydrophila injection $(P<0.05)$ and it was significant decreased at $24 \mathrm{~h}$ compared with $12 \mathrm{~h}$ after $A$. hydrophila injection in Diet \# B group $(P<0.05)$ (Figure 4B).

The ACP activity was significant higher in Diet \# D group than that in the other three diet groups $(P<0.05)$ at $12 \mathrm{~h}$ after $A$. hydrophila injection and it was significant increased at $24 \mathrm{~h}$ compared with $12 \mathrm{~h}$ after A. hydrophila injection in Diet \# A ( $P$ $<0.01)$, Diet \# B $(P<0.05)$ and Diet \# C $(P<0.05)$ groups (Figure 4C).

The ALP activity was significantly higher in Diet \# C and Diet \# D group at $12 \mathrm{~h}$ and it was significantly higher in Diet \# B, Diet \# C and Diet \# D at $24 \mathrm{~h}$ than in the control group after A. hydrophila injection $(P<0.05)$ (Figure 4D). Moreover, the ALP activity was significantly increased at $24 \mathrm{~h}$ compared with $12 \mathrm{~h}$ after $A$. hydrophila injection in all diet groups $(P<0.05$, $P<0.001, P<0.01, P<0.001$, respectively) (Figure 4D). The results showed that dietary supplementation of L-trp significantly improved the hematological immune status with A. hydrophila injection.

\section{Serum Antioxidant Capacity}

The SOD activity was significantly increased in Diet \# C and Diet \# D group at $12 \mathrm{~h}$, and significantly higher in Diet \# B, Diet \# C 
TABLE 3 | Effect of L-trp supplement on the serum antioxidant capacity in E. sinensis at 1, 7, and $14 \mathrm{~d}$.

\begin{tabular}{|c|c|c|c|c|c|}
\hline Item & Sample time & Diet \# A & Diet \# B & Diet \# C & Diet \# D \\
\hline \multirow{3}{*}{$\begin{array}{l}\text { SOD activity } \\
(\mathrm{U} / \mathrm{ml})\end{array}$} & $1 d$ & $82.90 \pm 7.08$ & $79.54 \pm 8.16$ & $81.84 \pm 6.03$ & $77.24 \pm 4.89$ \\
\hline & $7 d$ & $85.66 \pm 6.55$ & $86.78 \pm 3.78$ & $83.43 \pm 7.58$ & $84.54 \pm 8.68$ \\
\hline & $14 d$ & $88.72 \pm 4.77$ & $95.79 \pm 4.45$ & $89.61 \pm 10.98$ & $97.20 \pm 2.50$ \\
\hline \multirow{3}{*}{$\begin{array}{l}\text { GSH content } \\
(\mathrm{mg} / \mathrm{L})\end{array}$} & $1 d$ & $1.06 \pm 0.27$ & $1.20 \pm 0.34$ & $1.23 \pm 0.37$ & $1.25 \pm 0.50$ \\
\hline & $7 \mathrm{~d}$ & $0.98 \pm 0.28^{a}$ & $1.17 \pm 0.38^{a}$ & $1.85 \pm 0.41^{b}$ & $1.44 \pm 0.42^{\mathrm{ab}}$ \\
\hline & $14 d$ & $1.28 \pm 0.39^{a}$ & $1.47 \pm 0.37^{a b}$ & $1.44 \pm 0.27^{a b}$ & $1.87 \pm 0.22^{b}$ \\
\hline \multirow{3}{*}{$\begin{array}{l}\text { GSH-Px activity } \\
(\mu \mathrm{mol} / \mathrm{L})\end{array}$} & $1 d$ & $424.96 \pm 24.63$ & $414.52 \pm 43.04$ & $441.39 \pm 28.15$ & $411.91 \pm 55.13$ \\
\hline & $7 \mathrm{~d}$ & $408.78 \pm 65.04^{a}$ & $413.74 \pm 47.67^{a}$ & $441.91 \pm 28.97^{a}$ & $535.30 \pm 26.00^{b}$ \\
\hline & $14 d$ & $371.22 \pm 12.99$ & $387.91 \pm 62.76$ & $433.30 \pm 35.83$ & $387.39 \pm 88.46$ \\
\hline \multirow{3}{*}{$\begin{array}{l}\text { MDA content } \\
(\mathrm{nmol} / \mathrm{ml})\end{array}$} & $1 \mathrm{~d}$ & $12.26 \pm 2.26$ & $12.64 \pm 2.93$ & $12.03 \pm 2.64$ & $11.31 \pm 2.67$ \\
\hline & $7 \mathrm{~d}$ & $12.34 \pm 2.47$ & $11.46 \pm 2.19$ & $9.76 \pm 1.21$ & $11.05 \pm 2.02$ \\
\hline & $14 d$ & $11.58 \pm 2.69^{a}$ & $11.05 \pm 2.18^{\mathrm{ab}}$ & $7.98 \pm 1.88^{b}$ & $7.34 \pm 1.69^{b}$ \\
\hline
\end{tabular}

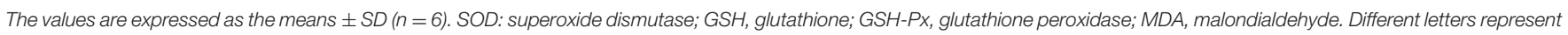
the significant differences between different groups at the same time $(P<0.05)$.

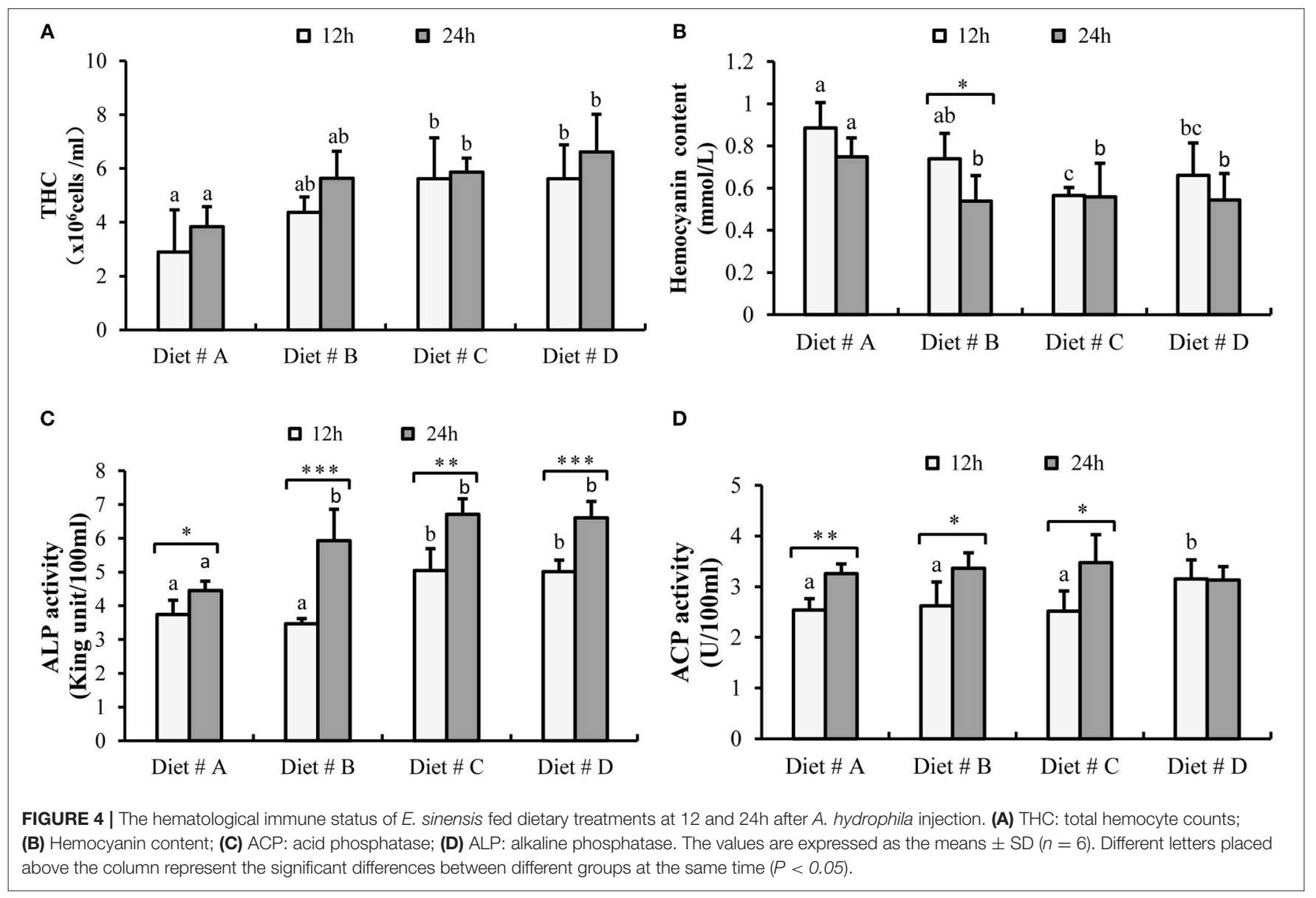

and Diet \# D at $24 \mathrm{~h}$ than in the control group after A. hydrophila injection $(P<0.05)$. Moreover, the maximum level was observed in Diet \# $C$ group at $24 \mathrm{~h}$ after $A$. hydrophila injection $(P<0.05)$ (Figure 6A).

The GSH content in Diet \# B, Diet \# C and Diet \# D groups was significantly higher than that in the control group after 12 and $24 \mathrm{~h}$ of $A$. hydrophila injection, and the maximum level was observed in Diet \# D group at $24 \mathrm{~h}$ after $A$. hydrophila injection $(P$ $<0.05)$. Moreover, the GSH content was significantly increased at $24 \mathrm{~h}$ compared with $12 \mathrm{~h}$ after A. hydrophila injection in Diet \# $\mathrm{A}$ and Diet \# B groups $(P<0.01)$ (Figure 6B).

The GSH-Px activity was significantly increased in Diet \# $\mathrm{C}$ and Diet \# D groups at $12 \mathrm{~h}$ and it was significant higher in Diet \# B at $24 \mathrm{~h}$ than that in the control group after 


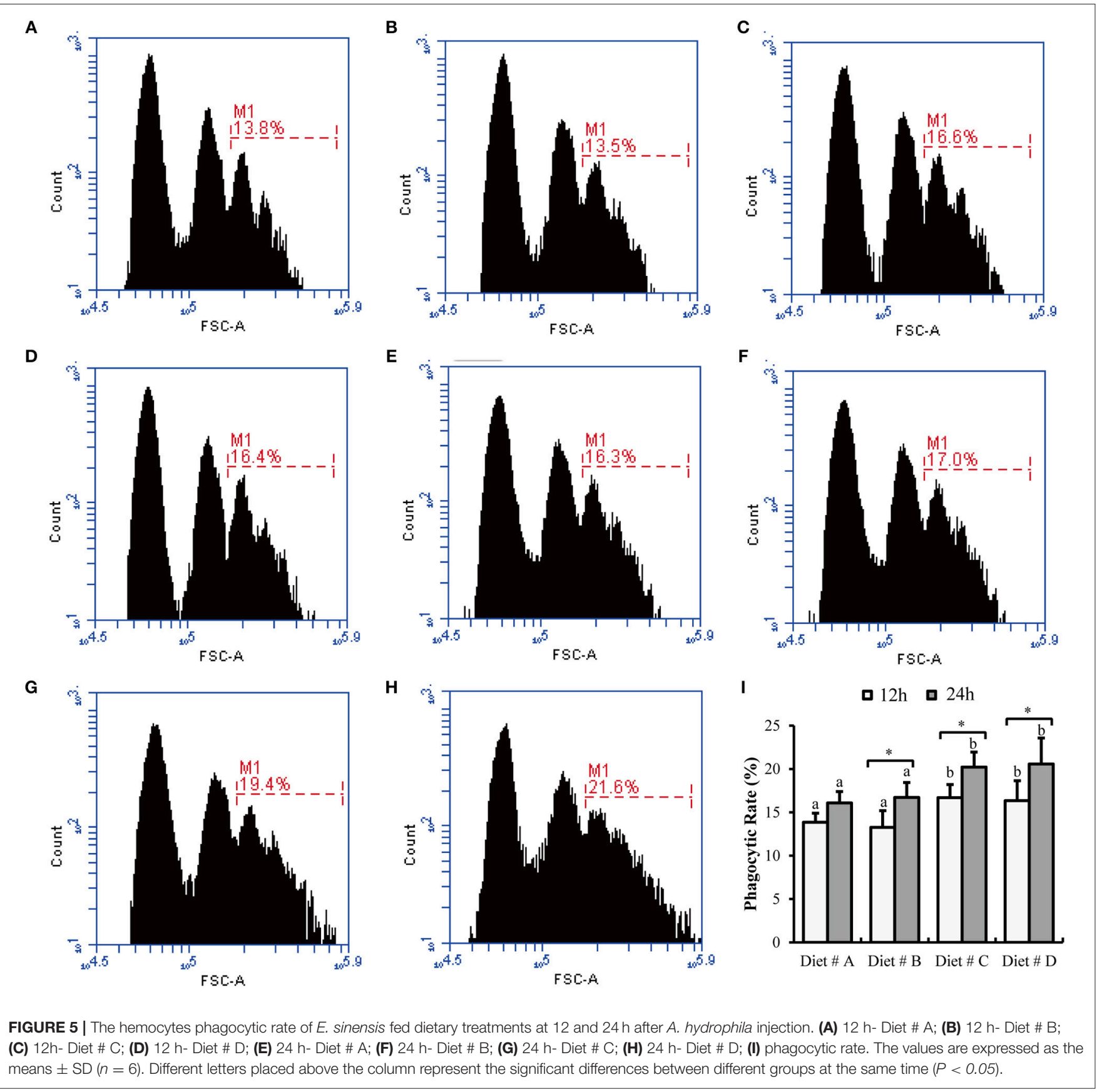

A. hydrophila injection $(P<0.05)$. Moreover, the GSH-Px activity was significantly increased at $24 \mathrm{~h}$ compared with $12 \mathrm{~h}$ after A. hydrophila injection in Diet \# B group $(P<0.05)$ (Figure 6C).

The MDA content was significantly lower in Diet \# C group than in the control group at $12 \mathrm{~h}$ after A. hydrophila injection $(P<0.05)$, whereas no significant difference among the four groups was observed at $24 \mathrm{~h}$ (Figure 6D). The results showed that dietary supplementation of L-trp significantly enhanced the serum antioxidant capacity of $E$. sinensis that had been injected with A. hydrophila.

\section{Antibacterial-Related Protein Genes Expressions}

The expression of EslecB-mRNA in the hepatopancreas was significantly higher in Diet \# C and Diet \# D group at $12 \mathrm{~h}$, whereas it was significantly lower in Diet \# C and Diet \# D group at $24 \mathrm{~h}$ than in the other two groups after $A$. hydrophila injection $(P<0.05)$ (Figure 7A). Moreover, the expression of EslecB-mRNA was significantly increased at $24 \mathrm{~h}$ compared with $12 \mathrm{~h}$ after $A$. hydrophila injection in Diet \# A $(P<0.001)$, Diet \# $\mathrm{B}(P<0.01)$, and Diet \# $\mathrm{C}(P<0.05)$ groups (Figure 7A).

The expression of EslecB-mRNA in hemocytes showed no significant difference among the four groups at $12 \mathrm{~h}$, whereas 


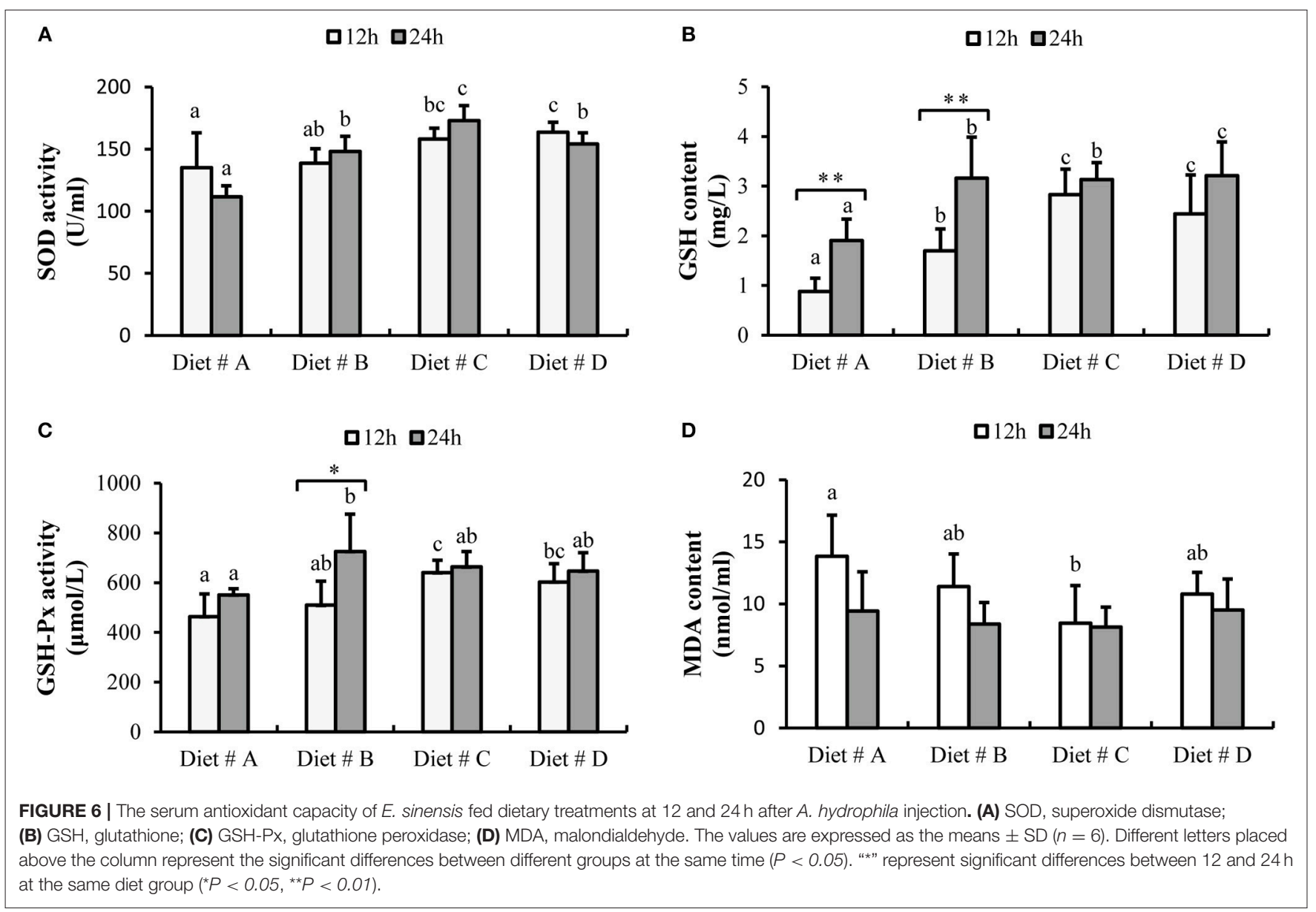

it was significantly higher in Diet \# C group at $24 \mathrm{~h}$ than in the other three groups after $A$. hydrophila injection $(P<$ 0.05) (Figure 7B). Moreover, the expression of EslecB-mRNA was significantly decreased at $24 \mathrm{~h}$ compared with $12 \mathrm{~h}$ after $A$. hydrophila injection in Diet \# A $(P<0.001)$, Diet \# B $(P<$ $0.001)$, Diet \# C $(P<0.001)$, and Diet \# D $(P<0.001)$ groups (Figure 7B).

The expression of EslecB-mRNA in intestine was significantly higher in Diet \# C and Diet \# D groups at $12 \mathrm{~h}$, whereas it was significantly lower in Diet \# C group at $24 \mathrm{~h}$ than in the control group after $A$. hydrophila injection $(P<0.05)$. Moreover, the expression of EslecB-mRNA was significantly increased at $24 \mathrm{~h}$ compared with $12 \mathrm{~h}$ after $A$. hydrophila injection in Diet \# A ( $P$ $<0.01)$, Diet \# B $(P<0.001)$, and Diet \# C $(P<0.05)$ groups (Figure 7C).

The expression of EslecB-mRNA in gill showed no significant difference among the four groups at 12 and $24 \mathrm{~h}$ after $A$. hydrophila injection. However, the expression of EslecB-mRNA was significantly decreased at $24 \mathrm{~h}$ compared with $12 \mathrm{~h}$ after $A$. hydrophila injection in Diet \# C $(P<0.01)$ and Diet \# D $(P<$ 0.01 ) groups (Figure 7D).

The expression of HSP 90-mRNA in hepatopancreas showed no significant difference among the four groups at 12 and $24 \mathrm{~h}$ after A. hydrophila injection. However, the expression of HSP
90-mRNA was significantly decreased at $24 \mathrm{~h}$ compared with $12 \mathrm{~h}$ after $A$. hydrophila injection in Diet \# A group $(P<0.05)$ (Figure 8A).

The expression of HSP 90-mRNA in hemocytes was significantly lower in Diet \# C and Diet \# D groups at $12 \mathrm{~h}(P$ $<0.05$ ), whereas there was no significant difference among the four groups at $24 \mathrm{~h}$ after $A$. hydrophila injection (Figure 8B). Moreover, the expression of HSP 90-mRNA was significantly decreased in Diet \# A $(P<0.05)$ and Diet \# B $(P<0.01)$ groups at $24 \mathrm{~h}$ compared with $12 \mathrm{~h}$ after $A$. hydrophila injection, whereas it was significantly increased in Diet \# C group at $24 \mathrm{~h}$ compared with $12 \mathrm{~h}$ after $A$. hydrophila injection $(P<0.05)$ (Figure $8 \mathrm{~B}$ ).

The expression of HSP 90 -mRNA in intestine was not significantly different among the four groups at $12 \mathrm{~h}$ after $A$. hydrophila injection $(P<0.05)$, whereas it was significantly higher in Diet \# C group than in the other three groups. Moreover, the expression of HSP 90-mRNA was significantly decreased in Diet \# A $(P<0.01)$ and Diet \# B $(P<0.05)$ groups at $24 \mathrm{~h}$ compared with $12 \mathrm{~h}$ after $A$. hydrophila injection (Figure 8C).

The expression of HSP 90-mRNA in gill showed no significant difference among the four groups at $12 \mathrm{~h}$ after $A$. hydrophila injection, whereas it was significantly lower in Diet \# D group than in the control group $(P<0.05)$. Moreover, the expression 


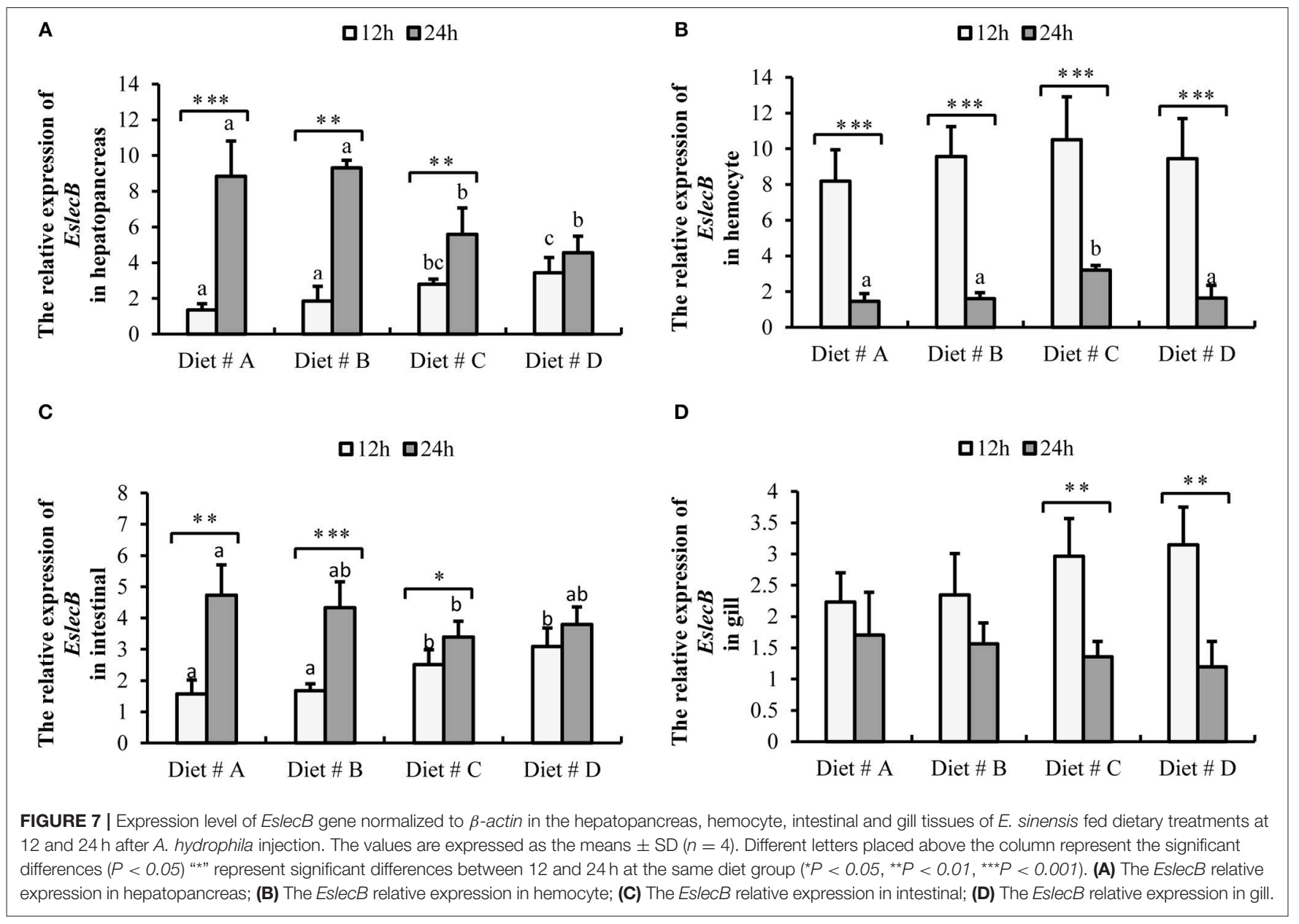

of HSP 90-mRNA was significantly increased in Diet \# A ( $P$ $<0.001)$ and Diet \# C $(P<0.05)$ groups at $24 \mathrm{~h}$ compared with $12 \mathrm{~h}$ after $A$. hydrophila injection (Figure 8D). The results showed that dietary supplementation of L-trp significantly upregulated the antibacterial-related protein genes expression levels of $E$. sinensis that were injected with $A$. hydrophila. Thus, the antibacterial ability of $E$. sinensis was significantly improved with dietary supplementation of L-trp.

\section{DISCUSSION}

\section{The Effects of Dietary L-trp Supplementation on Hematological Immunity}

Crustaceans lack an acquired immune system and only possess an innate immune system, which includes hematological and cellular immunity. Several studies on crustaceans have demonstrated that hematological parameters are important parameters for assessing their immune response ability, such as THC, and hematological immune-related proteins and enzymes (36-38). In this study, we determined the effects of dietary L-trp supplementation on the hematological parameters of left cheliped autotomized E. sinensis, as well as, the effects on hematological immunity and disease resistance, THC in crustaceans is a commonly used performance parameter for assessing cellular immunity (39). Hemocyte immunity mainly includes phagocytosis, package action, agglutination, and melanization of hemocyte, and participate in the removal of pathogens (25). Moreover, hemocyte phagocytosis is widely used to assess the antibacterial ability in invertebrates (26). In the present study, we found that dietary L-trp supplementation significantly increased the THC levels in E. sinensis at 7 and $14 \mathrm{~d}$. We speculated that the wound is susceptible to pathogens after limb autotomy of E. sinensis, and the increase in THC level can accelerate the removal of foreign bodies and substance transport in the body. In trial 2, we found that the THC levels in Diet \# C and Diet \# D group were significantly higher than those in the control group after 12 and $24 \mathrm{~h}$ of $A$. hydrophila injection. Moreover, the phagocytic activity of hemocyte in Diet \# C and Diet \# $\mathrm{D}$ groups was significantly higher than that in the control group after $12 \mathrm{~h}$ and $24 \mathrm{~h}$ of $A$. hydrophila injection. It indicates that supplementation of L-trp in diet can significantly increase the THC levels and the ability of pathogens removal. (17) reported that supplementation of $3 \%$ TRP in diet significantly increased the hemocyte phagocytic activity of Apostichopus japonicus Selenka, which was consistent with our results. 


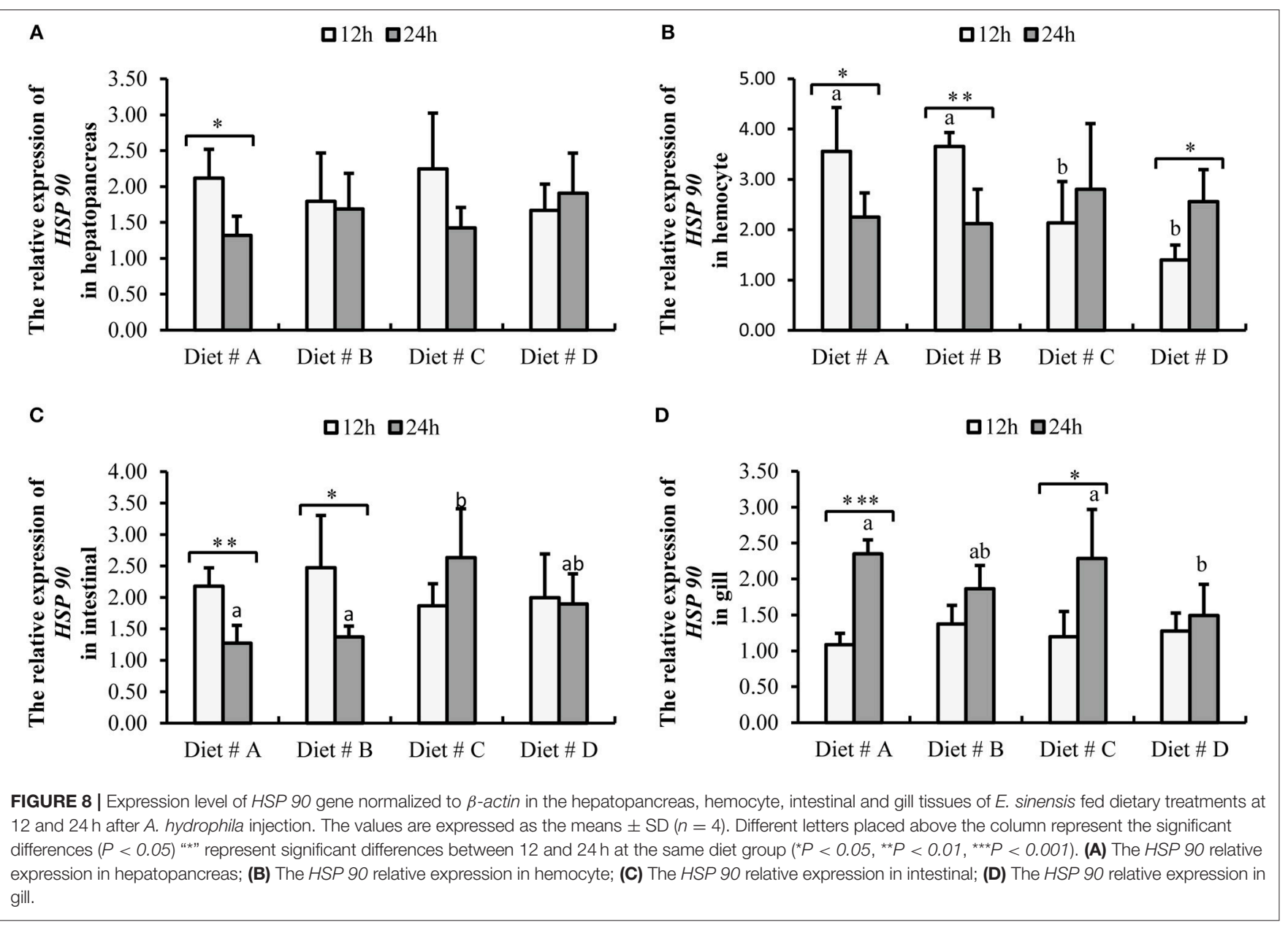

Hemocyanin is an important multifunctional protein in crustaceans, that is found mainly in the hemolymph, and accounts for more than $90 \%$ of serum total protein (40-42). In addition to the function of carrying oxygen, transporting metal ions, storing protein and regulating osmotic pressure, hemocyanin exhibits antibacterial, antiviral, and phenoloxidase activity under certain conditions, and is an important participant of immune defense system $(22,43)$. The hemocyanin content in the hemolymph acts as a good indication of the health status of crustaceans (44). In trial 1, we observed a similar trend in hemocyanin contents and THC levels, wherein the hemocyanin content in Diet \# C group was significantly higher than that in other diet groups. The results showed that dietary L-trp supplementation can improve the hematological immunity and anti-stress ability of E. sinensis, similar to the results of a study on Apostichopus japonicus Selenka (17). However, we observed in the results of trial 2 that the hemocyanin content was significantly lower in the L-trp supplement group than in the control group after injection of $A$. hydrophila. Moreover, the hemocyanin content of all the diet groups showed a trend of reduction at $24 \mathrm{~h}$ compared with $12 \mathrm{~h}$ after A. hydrophila injection. We speculate that the hemocyte phagocytic activity, antibacterial ability and ability of foreign bodies body removal in the L-trp supplementation groups were significantly enhanced, resulting in a large consumption of hemocyanin not being timely supplemented. Machado et al. found that the concentration of hemoglobin was significantly lower in the tryptophan supplement group than in the control group in Dicentrarchus labrax after infection with Photobacterium damselae subsp. piscicida (Phdp) (15). Qin et al. found a significant increase in THC at $12 \mathrm{~h}$ after infection with A. hydrophila in E. sinensis (45), similar to our results.

When a pathogen is phagocytosed by phagocytic cells, it fuses with lysosomes and is eventually hydrolyzed by various hydrolases. Hydrolases not only exist in cells, but are also widely distributed in the serum by means of degranulation, to form a hydrolase system, which plays an important role in the serum immune defense. They are considered to be important nonspecific indicators of crustaceans, as ALP and ACP levels reflect the health status of aquatic animals $(23,46)$. In the present study, we observed that dietary supplementation with $0.70 \%$ L-trp significantly increased the ACP activity at $12 \mathrm{~h}$ after $A$. hydrophila injection, and ACP activity was significantly higher at $24 \mathrm{~h}$ than that at $12 \mathrm{~h}$ in the other three dietary group. ALP activity showed a similar trend. Dietary supplementation of L-trp significantly increased the activity of ACP and ALP in the serum, which was 
beneficial in accelerating the body metabolism and enhanced the ability of crabs to remove pathogenic bacteria. Previous study reported that dietary supplementation of tryptophan can significantly increase ACP activity in the plasma of Dicentrarchus labrax (15). Christophermarlowea et al. reported that the ALP activity of Gadus morhua L. was increased after exposure to a crowding stress during the latter part of the post-stress period (47). In this study, dietary supplementation of L-trp could improve the resistance to pathogens in crabs to some extent.

\section{The Effects of Dietary L-trp Supplementation on Hemolymph Antioxidant Capacity}

When invertebrates are attacked by foreign pathogens, oxygen is released to enhance resistance to prevent infection with pathogens $(27,28)$. Therefore, the antioxidant system is an important immune defense system for crustaceans. In addition, hemocyte can adhere to pathogens, trigger phagocytosis, and produce highly toxic reactive oxygen species (ROS) (48). Various antioxidant enzymes, oxidases and hydrolases play important roles before phagocytosis, during phagocytosis, and after phagocytosis. In crustaceans, the production of ROS is an important indicator of cell defense (27). ROS is indispensable for normal cell functions (such as redox signals and anti-pathogens), but excessive ROS can cause oxidative damage to tissues, such as oxidative damage of DNA, cell membranes, proteins, and enzymes (49). In order to prevent oxidative damage to the organism by excessive ROS, the antioxidant defense system gets activated and removes excess ROS. Superoxide dismutase (SOD), glutathione peroxidase (GSH-Px), and glutathione (GSH) are important members of the crustacean antioxidant defense system (24). In the present study, although dietary supplementation of L-trp had no significant effect on SOD activity, the GSH content with dietary supplementation of $0.53 \% \mathrm{~L}$-trp at $7 \mathrm{~d}$ 0.70\% L-trp at $14 \mathrm{~d}$ was significantly higher than that of the control group. In the group with dietary supplementation $0.70 \%$ L-trp, GSHPx activity at $7 \mathrm{~d}$ was significantly higher than that in other groups. Moreover, we observed that dietary supplementation with L-trp significantly increased the serum antioxidant capacity of E. sinensis at 12 and $24 \mathrm{~h}$ after infection with A. hydrophila. Studies have reported that L-trp can increase the SOD activity of Apostichopus japonicus Selenka (17). Mardones et al. reported that dietary tryptophan significantly reduced cortisol levels in the plasma of Salmo salar and Oncorhynchus kisutch, enhancing their anti-stress ability (50). In rats, a lack of Trp in the diet leads to a decrease in GSH-Px activity in liver tissue. In rats, a lack of tryptophan in the diet leads to a decrease in GSH-Px activity in liver tissue (51). As the main decomposition product of lipid peroxidation, MDA can reflect the degree of lipid peroxidation in the body and the degree of oxidative damage in cells (52). In this study, dietary supplementation with 0.53 and $0.70 \% \mathrm{~L}-$ trp significantly reduced the serum MDA levels at $14 \mathrm{~d}$. The MDA levels in dietary supplementation groups of $0.53 \%$ L-trp and $0.70 \%$ L-trp were significantly lower than those in control group at 12 and $24 \mathrm{~h}$ after infection with A. hydrophila. This result indicated that dietary supplementation of proper L-trp can inhibit lipid peroxidation in E. sinensis. Niyogi et al. reported that MDA levels were negatively correlated with antioxidant enzyme activity (53). Previous studies have shown that tryptophan can reduce MDA levels in rat liver (54). Wen et al. reported that dietary supplementation of tryptophan significantly reduced the MDA levels in the gut of Ctenopharyngodon idella, and significantly increased the SOD and GSH-Px activity, as well as, GSH content (16), which is consistent with our results.

\section{The Effects of Dietary L-trp Supplementation on Gene Expression of Anti-bacterial-Related Protein}

In invertebrates, C-type lectin can participate in pathogen recognition and binding, agglutination, antibacterial, hemocyte encapsulation, activation of prophenoloxidase (proPO) activation system and other immune responses (55-59). Many studies have reported that some C-type lectins in $E$. sinensis, such as EsLecA, EslecG, EslecD, and EslecF, can promote hemocyte encapsulation and antibacterial activity in antibacterial reactions (60-62). In addition, it has been reported that C-type lectin immulectin-2 has the effect of inducing phagocytosis in Manduca sexta (59). As a congenital immune-related gene, C-type lectin $E s l e c B$ participates in immune defense responses such as microbial binding, cell agglutination, and defense against bacterial attack in E. sinensis (21). The hemocytes, hepatopancreas, and gills are considered the important tissues involved in immunity of crustaceans. Hemocytes are involved in the recognition and phagocytosis of pathogenic bacteria. Hepatopancreas is responsible for hematopoiesis, immunity, detoxification, digestion, and other physiological functions. As an important respiratory organ and excretory organ, gill can isolate the body from the surrounding microorganisms, effectively avoid infection, and resist the invasion of pathogenic bacteria $(25,58,63)$. As a complex micro-ecological system, the intestines have the dual functions of digestion, absorption and disease defense (64). Therefore, in this study, we used qRT-PCR to detect the expression of antibacterial-related protein genes $E s L e c B$ and HSP 90 in hepatopancreas, hemocytes, gill and intestine of E. sinensis after injection of $A$. hydrophila. The results showed that the expression of $E s L e c B$ gene in the hepatopancreas, hemocytes, and gill was significantly up-regulated at $12 \mathrm{~h}$ after the injection of $A$. hydrophila in the dietary supplementation group with $0.53 \%$ L-trp. This indicates that dietary supplementation with L-trp accelerated the antibacterial and immune defense responses. Moreover, the expression of $E s L e c B$ gene in hemocytes and intestine was significantly lower at 24 than at $12 \mathrm{~h}$ after the injection of $A$. hydrophila, whereas the expression of EsLecB gene in hepatopancreas and gill was significantly higher at $24 \mathrm{~h}$ than at $12 \mathrm{~h}$ after the injection of $A$. hydrophila in all diet groups. The results showed that, in order to resist the attack of $A$. hydrophila, hemocytes and intestine are the primary agents of antibacterial defense function in the early stage, which may be related to the induction of hemocyte phagocytosis. Thereafter, the hepatopancreas, and gill act together act as the main functional unit to exert immune defense function. 
Heat shock protein HSP 90 is an important disease-resistant and anti-inverse factor in animals. It is an important molecular chaperone, and plays an important role in resisting the invasion of pathogens, and regulating immune function and anti-aging (20). Studies have found that when Charybdis japonica was exposed to disrupting chemicals (EDCs), such as bisphenol A (BPA) and 4-nonylphenol (NP), the expression of the HSP 90 gene in crab tissue was significantly increased in a short time (65). In this study, we found that the HSP 90 gene expression in the hepatopancreas, intestine, and gill was no significantly difference among the four diet groups at $12 \mathrm{~h}$ after the injection of A. hydrophila, whereas the HSP 90 gene expression in the intestine was significantly up-regulated at $24 \mathrm{~h}$ after the injection of $A$. hydrophila in Diet \# C group compared with the control group. However, the HSP 90 gene expression in gill was significant down-regulated at $24 \mathrm{~h}$ after the injection of A. hydrophila in Diet \# D group compared with the control group. After the infection of A. hydrophila in E. sinensis, the expression of HSP 90 gene varied across different tissues, which may be related to the divergent functions of different tissues in the immune defense system. Our previous study found that eyestalk ablation could lead to a significant up-regulation of HSP 90 gene expression in hemocytes to improve the body's anti-stress response (11). In the present study, the expression of HSP 90 gene in hemocytes was significantly lower in Diet \# C and Diet \# D groups than in the control group at $12 \mathrm{~h}$ after the injection of A. hydrophila, whereas there was no significant difference among the four groups at $24 \mathrm{~h}$ after the injection of A. hydrophila. The results showed that dietary supplementation of L-trp can enhance the body's anti-stress ability to a certain extent in a short period of time.

\section{CONCLUSION}

In summary, dietary supplementation of L-trp can enhance the antioxidant capacity, improve the hematological immune status, and increase the survival rate of $E$. sinensis under cheliped autotomy stress. Moreover, the bacterial challenge test results

\section{REFERENCES}

1. Thomas CW, Carter CG, Crear BJ. Feed availability and its relationship to survival, growth, dominance and the agonistic behaviour of the southern rock lobster, Jasus edwardsii in captivity. Aquaculture (2003) 215:45-65. doi: 10.1016/S0044-8486(01)00899-7

2. Riquelme-Bugueño R. Incidence patterns of limb autotomy in the estuarine crab, Hemigrapsus crenulatus (H. Milne Edwards, 1837) (Brachyura, Grapsoidea) from a temperate Estuary in the Eastern South Pacific. Crustaceana (2006) 79:925-32. doi: 10.1163/156854006778815973

3. Sui L, Wille $\mathrm{M}$, Cheng $\mathrm{Y}, \mathrm{Wu} \mathrm{X}$, Sorgeloos $\mathrm{P}$. Larviculture techniques of Chinese mitten crab Eriocheir sinensis. Aquaculture (2011) 315:16-9. doi: 10.1016/j.aquaculture.2010.06.021

4. Lipcius RN, Herrnkind WF. Molt cycle alterations in behavior, feeding and diel rhythms of a decapod crustacean, the spiny lobster Panulirus argus. Mar Biol. (1982) 68:241-52. doi: 10.1007/BF00409591

5. Fleming PA, Muller D, Bateman PW. Leave it all behind: a taxonomic perspective of autotomy in invertebrates. Biol Rev Camb Philos Soc. (2007) 82:481-510. doi: 10.1111/j.1469-185X.2007.00020.x showed that dietary supplementation of L-trp can enhance the immune defense against bacterial attack by regulating the hemocyte phagocytosis, hydrolase and antioxidant defense systems, and expression of antibacterial-related protein genes. This study evaluated the effects of dietary supplementation of L-trp on the hematological immune, antioxidant capacity, anti-stress, and antibacterial ability of E. sinensis, which can provide scientific guidance for improving the anti-stress and disease resistance of $E$. sinensis from the perspective of nutrition.

\section{DATA AVAILABILITY}

The data underlying this study can be found in Data Sheet $\mathbf{1}$ in the Supplementary Material.

\section{AUTHOR CONTRIBUTIONS}

CZ designed the experiment and wrote the article. QZ determined the hematological immune parameters. XS determined the expression level of antibacterial-related protein genes. YP and YS assisted in collecting samples. YC provided funding support. XY guided the experiment design and the writing of the article.

\section{FUNDING}

This work was supported by the Aquaculture Engineering Research Platform in Shanghai Established by Shanghai Science and Technology Commission [grant number 16DZ2281200], and the China Agriculture Research System [grant number CARS-48].

\section{SUPPLEMENTARY MATERIAL}

The Supplementary Material for this article can be found online at: https://www.frontiersin.org/articles/10.3389/fimmu. 2018.02744/full\#supplementary-material

6. Brock RE, Smith LD. Recovery of Claw Size and Function Following Autotomy in Cancer productus (Decapoda: Brachyura). Biol Bull. (1998) 194:53-62. doi: 10.2307/1542513

7. Simonson JL. Reversal of handedness, growth, and claw stridulatory patterns in the stone crab Menippe mercenaria (Say) (Crustacea: Xanthidae). J Crustacean Biol. (1985) 5:281-93. doi: 10.2307/1547875

8. Yang XZ, Zhang C, Huang GY, Xu MJ, Cheng YX, Yang ZG, et al. Cellular and biochemical parameters following autotomy and ablation-mediated cheliped loss in the Chinese mitten crab, Eriocheir sinensis. Dev Comp Immunol. (2017) 81:33-43. doi: 10.1016/j.dci.2017.11.003

9. Zhao HL, Jie HE, Xu-Gan WU, Long XW, Hao L, Cheng YX. Study of limb autotomy patterns of juvenile Chinese mitten crab(Eriocheir sinensis) reared in earth ponds. J Biol. (2015) 32:10-13. doi: 10.3969/j.issn.2095-1736.2015.01.010

10. He J, Wu X, Cheng Y. Effects of limb autotomy on growth, feeding and regeneration in the juvenile Eriocheir sinensis. Aquaculture (2016) 457:79-84. doi: 10.1016/j.aquaculture.2016.02.004

11. Zhang C, Pang Y, Zhang Q, Huang G, Xu M, Tang B, et al. Hemolymph transcriptome analysis of Chinese mitten crab (Eriocheir sinensis) with intact, 
left cheliped autotomy and bilateral eyestalk ablation. Fish Shellfish Immunol. (2018) 81:266-75. doi: 10.1016/j.fsi.2018.07.025

12. Grimble RF. Basics in clinical nutrition: immunonutrition - nutrients which influence immunity: effect and mechanism of action. e-SPEN Eur E-J Clin Nutr Metabol. (2009) 4:e10-3. doi: 10.1016/j.eclnm.2008. 07.017

13. Wu GY. Amino acids: metabolism, functions, and nutrition. Amino Acids (2009) 37:1-17. doi: 10.1007/s00726-009-0269-0

14. Morandini L, Ramallo MR, Moreira RG, Höcht C, Somoza GM, Silva A, et al. Serotonergic outcome, stress and sexual steroid hormones, and growth in a South American cichlid fish fed with an L-tryptophan enriched diet. Gen Comp Endocrinol. (2015) 223:27-37. doi: 10.1016/j.ygcen.2015.10.005

15. Machado M, Azeredo R, Díaz-Rosales P, Afonso A, Peres H, Oliva-Teles A, et al. Dietary tryptophan and methionine as modulators of European seabass (Dicentrarchus labrax) immune status and inflammatory response. Fish Shellfish Immunol. (2015) 42:353-62. doi: 10.1016/j.fsi.2014.11.024

16. Wen H, Feng L, Jiang W, Liu Y, Jiang J, Li S, et al. Dietary tryptophan modulates intestinal immune response, barrier function, antioxidant status and gene expression of TOR and Nrf2 in young grass carp (Ctenopharyngodon idella). Fish Shellfish Immunol. (2014) 40:275-87. doi: 10.1016/j.fsi.2014.07.004

17. Zhang E, Dong S, Wang F, Tian X, Gao Q. Effects of l-tryptophan on the growth, intestinal enzyme activities and non-specific immune response of sea cucumber (Apostichopus japonicus Selenka) exposed to crowding stress. Fish Shellfish Immunol. (2018) 75:158-63. doi: 10.1016/j.fsi.2018. 01.009

18. Sanchez VFJ. Biology of European Seabass. Boca Raton, FL: CRC Press (2014).

19. Li Y, Wu TT, Tan XD. Effects of levamisole on the non-specific immune response and disease resistance of Chinese mitten crab Eriocheir sinensis. $J$ Fish China (2007) 31:785-91.

20. Pandey P, Saleh A, Nakazawa A, Kumar S, Srinivasula SM, Kumar V, et al. Negative regulation of cytochromeÂ c-mediated oligomerization of Apaf-1 and activation of procaspase-9 by heat shock proteinÂ 90 . Embo J. (2000) 19:4310-22. doi: 10.1093/emboj/19.16.4310

21. Fang ZY, Li D, Li XJ, Zhang X, Zhu YT, Li WW, et al. A single CRD C-type lectin from Eriocheir sinensis (EsLecB) with microbialbinding, antibacterial prophenoloxidase activation and hem-encapsulation activities. Fish Shellfish Immunol. (2016) 50:175-90. doi: 10.1016/j.fsi.2016. 01.031

22. Decker H, Hellmann N, Jaenicke E, Lieb B, Meissner U, Markl J. Minireview: recent progress in hemocyanin research. Integr Comp Biol. (2007) 47:631-44. doi: $10.1093 / \mathrm{icb} / \mathrm{icm} 063$

23. Lin S, Pan Y, Luo L, Luo L. Effects of dietary $\beta$-1,3-glucan, chitosan or raffinose on the growth, innate immunity and resistance of koi ( Cyprinus carpio koi ). Fish Shellfish Immunol. (2011) 31:788. doi: 10.1016/j.fsi.2011.07.013

24. Zhao YT, Xu-Gan WU, Chang GL, Qiu RJ, Cheng YX. Effects of dietary DHA Levels on growth, lipid composition and hypoxia stress of juvenile Chinese mitten crab Eriocheir sinensis. Acta Hydrobiol Sinica (2013) 37:1133-44. doi: 10.7541/2013.154

25. Jiravanichpaisal P, Lee BL, Söderhäll K. Cell-mediated immunity in arthropods: Hematopoiesis, coagulation, melanization and opsonization. Immunobiology (2006) 211:213-36. doi: 10.1016/j.imbio.2005.10.015

26. Zhao Y, Zhang W, Xu W, Mai K, Zhang Y, Liufu Z. Effects of potential probiotic Bacillus subtilis $\mathrm{T} 13$ on growth, immunity and disease resistance against Vibrio splendidus infection in juvenile sea cucumber Apostichopus japonicus. Fish Shellfish Immunol. (2012) 32:750-5. doi: $10.1016 /$ j.fsi.2012.01.027

27. Wu YS, Lee MC, Huang CT, Kung TC, Huang CY, Nan FH. Effects of traditional medical herbs "minor bupleurum decoction" on the non-specific immune responses of white shrimp (Litopenaeus vannamei). Fish Shellfish Immunol. (2017) 64:218-25. doi: 10.1016/j.fsi.2017.03.018

28. Canesi L, Gallo G, Gavioli M, Pruzzo C. Bacteria-hemocyte interactions and phagocytosis in marine bivalves. Microsc Res Tech. (2002) 57:469-76. doi: 10.1002/jemt.10100

29. Zhang C, Yang XZ, Xu MJ, Huang GY, Zhang Q, Cheng YX, et al. Melatonin promotes cheliped regeneration, digestive enzyme function, and immunity following autotomy in the chinese mitten Crab, Eriocheir sinensis. Front Physiol. (2018) 9:269-80. doi: 10.3389/fphys.2018.00269

30. Esteban S, Nicolaus C, Garmundi A, Rial RV, Rodríguez AB, Ortega E, et al. Effect of orally administered L-tryptophan on serotonin, melatonin, and the innate immune response in the rat. Mol Cell Biochem. (2004) 267:39-46. doi: 10.1023/B:MCBI.0000049363.97713.74

31. Höglund E, Sørensen C, Bakke MJ, Nilsson GE, Overli O. Attenuation of stress-induced anorexia in brown trout (Salmo trutta) by pretreatment with dietary l-tryptophan. Br J Nutr. (2007) 97:786-9. doi: 10.1017/S0007114507450280

32. Laranja JLQ, Jr, Quinitio ET, Catacutan MR, Coloso RM. Effects of dietary L-tryptophan on the agonistic behavior, growth and survival of juvenile mud crab Scylla serrata. Aquaculture (2010) 310:84-90. doi: 10.1016/j.aquaculture.2010.09.038

33. Harlioglu MM, Harlioglu AG, Yonar SM, Duran T. Effects of dietary ltryptophan on the agonistic behavior, growth, and survival of freshwater crayfish Astacus leptodactylus Eschscholtz. Aquacult Int. (2014) 22:733-48. doi: 10.1007/s10499-013-9702-1

34. Conceição LE, Aragão C, Dias J, Costas B, Terova G, Martins C, et al. Dietary nitrogen and fish welfare. Fish Physiol Biochem. (2012) 38:119-41. doi: 10.1007/s10695-011-9592-y

35. Nickerson KW, Holde KEV. A comparison of molluscan and arthropod hemocyanin-I. Circular dichroism and absorption spectra. Com Biochem Phys B. (1971) 39:855-72. doi: 10.1016/0305-0491(71)90109-X

36. Cheng $\mathrm{W}$, Chen JC. Effects of $\mathrm{pH}$, temperature and salinity on immune parameters of the freshwater prawn Macrobrachium rosenbergii. Fish Shellfish Immunol. (2000) 10:387-91. doi: 10.1006/fsim.2000.0264

37. Powell A, Rowley AF. The effect of dietary chitin supplementation on the survival and immune reactivity of the shore crab, Carcinus maenas. Comp Biochem Physiol A Mol Integr Physiol. (2007) 147:122-8. doi: 10.1016/j.cbpa.2006.12.027

38. Vogan CL, Rowley AF. Effects of shell disease syndrome on the haemocytes and humoral defences of the edible crab, Cancer pagurus. Aquaculture (2002) 205:237-52. doi: 10.1016/S0044-8486(01)00703-7

39. Van CB, Botterblom MH, Liu W, Taverne N, Van WP, Rombout JH. The role of the haematopoietic tissue in haemocyte production and maturation in the black tiger shrimp (Penaeus monodon). Fish Shellfish Immunol. (2002) 12:253-72. doi: 10.1006/fsim.2001.0369

40. Galindo C, Gaxiola G, Cuzon G, Chiappacarrara X. Physiological and Biochemical Variations during the Molt Cycle in Juvenile Litopenaeus vannamei under Laboratory Conditions. J Crustacean Biol. (2009) 29:544-49. doi: 10.1651/08-3094.1

41. Lee SY, Lee BL, Söderhäll K. Processing of an antibacterial peptide from hemocyanin of the freshwater crayfish Pacifastacus leniusculus. J Biol Chem. (2003) 278:7927-33. doi: 10.1074/jbc.M209239200

42. Zhang $\mathrm{X}$, Huang CQ. Antiviral properties of hemocyanin isolated from shrimp Penaeus monodon. Antivir Res. (2004) 61:93-9. doi: 10.1016/j.antiviral.2003.08.019

43. Pan LQ, Jin CX. A review on hemocyanins of crustacean. J Fish China (2008) 32:484-91. doi: 10.3724/SP.J.00001

44. Chen JC, Cheng SY. Hemolymph $\mathrm{PCO}_{2}$, hemocyanin, protein levels and urea excretions of Penaeus monodon exposed to ambient ammonia. Aquat Toxicol. (1993) 27:281-91. doi: 10.1016/0166-445X(93)90059-A

45. Qin F, Shi M, Yuan H, Yuan L, Lu W, Zhang J, et al. Dietary nano-selenium relieves hypoxia stress and, improves immunity and disease resistance in the Chinese mitten crab (Eriocheir sinensis). Fish Shellfish Immunol. (2016) 54:481-8. doi: 10.1016/j.fsi.2016.04.131

46. Xue QG, Renault T. Enzymatic activities in European flat oyster, Ostrea edulis, and Pacific oyster, Crassostrea gigas, Hemolymph. J Invertebr Pathol. (2000) 76:155-63. doi: 10.1006/jipa.2000.4965

47. Christophermarlowea C, Ingvild B, Monicaf B, Viswanath K. Shortterm crowding stress in Atlantic cod, Gadus morhua L. modulates the humoral immune response. Aquaculture (2009) 295:110-5. doi: 10.1016/j.aquaculture.2009.06.036

48. Chisholm JR, Smith VJ. Comparison of antibacterial activity in the hemocytes of different crustacean species. Comp Biochem Physiol A Physiol. (1995) 110:39-45. doi: 10.1016/0300-9629(94)00157-O

49. Valavanidis A, Vlahogianni T, Dassenakis M, Scoullos M. Molecular biomarkers of oxidative stress in aquatic organisms in relation to toxic environmental pollutants. Ecotoxicol Environ Saf. (2006) 64:178-89. doi: 10.1016/j.ecoenv.2005.03.013

50. Mardones O, Devia E, Labbé BS, Oyarzún R, Vargas-Chacoff L, Muñoz JLP. Effect of L-tryptophan and melatonin supplementation on the serotonin gastrointestinal content and digestive enzymatic activity for 
Salmo salar and Oncorhynchus kisutch. Aquaculture (2018) 482:203-10. doi: 10.1016/j.aquaculture.2017.10.003

51. Raju TN, Kanth VR, Reddy PU. Influence of kynurenines in pathogenesis of cataract formation in tryptophan-deficient regimen in Wistar rats. Indian $J$ Exp Biol. (2007) 45:543-8.

52. Draper HH, Hadley M. Malondialdehyde determination as index of lipid peroxidation. Methods Enzymol. (1990) 186:421-31. doi: 10.1016/0076-6879(90)86135-I

53. Niyogi S, Biswas S, Sarker S, Datta AG. Seasonal variation of antioxidant and biotransformation enzymes in barnacle, Balanus balanoides, and their relation with polyaromatic hydrocarbons. Mar Environ Res. (2001) 52:13-26. doi: 10.1016/S0141-1136(00)00257-9

54. Livingstone DR. Oxidative stress in aquatic organisms in relation to pollution and aquaculture. Revue De Médecine Vétérinaire. (2003) 154:427-30.

55. Bachère E, Gueguen Y, Gonzalez M, Lorgeril JD, Garnier J, Romestand B. Insights into the anti-microbial defense of marine invertebrates: the penaeid shrimps and the oyster Crassostrea gigas. Immunol Rev. (2010) 198:149-68. doi:10.1111/j.0105-2896.2004.00115.x

56. Cerenius L, Lee BL, Söderhäll K. The proPO-system: pros and cons for its role in invertebrate immunity. Trends Immunol. (2008) 29:263-71. doi: 10.1016/j.it.2008.02.009

57. Pan J, Kurosky A, Xu B, Chopra AK, Coppenhaver DH, Singh IP, et al. Broad antiviral activity in tissues of crustaceans. Antiviral Res. (2000) 48:39-47. doi: 10.1016/S0166-3542(00)00117-0

58. Wang XW, Wang JX. Diversity and multiple functions of lectins in shrimp immunity. Dev Comp Immunol. (2013) 39:27. doi: 10.1016/j.dci.2012. 04.009

59. Yu XQ, Kanost MR. Manduca sexta lipopolysaccharide-specific immulectin-2 protects larvae from bacterial infection. Dev Comp Immunol. (2003) 27:18996. doi: 10.1016/S0145-305X(02)00099-X

60. Jin XK, Li S, Guo XN, Cheng L, Wu MH, Tan SJ, et al. Two antibacterial C-type lectins from crustacean, Eriocheir sinensis, stimulated cellular encapsulation in vitro. Dev Comp Immunol. (2013) 41:544-52. doi: 10.1016/j.dci.2013.07.016
61. Wang L, Wang L, Zhang D, Li F, Wang M, Huang M, et al. A novel Ctype lectin from crab Eriocheir sinensis functions as pattern recognition receptor enhancing cellular encapsulation. Fish Shellfish Immunol. (2013) 34:832. doi: 10.1016/j.fsi.2012.12.010

62. Jin XK, Guo XN, Li S, Wu MH, Zhu YT, Yu AQ, et al. Association of a hepatopancreas-specific C-type lectin with the antibacterial response of Eriocheir sinensis. PLoS ONE (2013) 8:e76132. doi: 10.1371/journal.pone. 0076132

63. Gross PS, Bartlett TC, Browdy CL, Chapman RW, Warr GW. Immune gene discovery by expressed sequence tag analysis of hemocytes and hepatopancreas in the Pacific White Shrimp, Litopenaeus vannamei, and the Atlantic White Shrimp, L. setiferus. Dev Comp Immunol. (2001) 25:565-77. doi: 10.1016/S0145-305X(01)00018-0

64. Li Q, Xie J, He L, Wang $\mathrm{Y}$, Duan $\mathrm{Z}$, Yang $\mathrm{H}$, et al. Identification of ADAM10 and ADAM17 with potential roles in the spermatogenesis of the Chinese mitten crab, Eriocheir sinensis. Gene (2015) 562:117-27. doi: 10.1016/j.gene.2015.02.060

65. Park K, Kwak IS. Characterize and Gene Expression of Heat Shock Protein 90 in Marine Crab Charybdis japonica following Bisphenol A and 4-Nonylphenol Exposures. Environ Health Toxicol. (2014) 29:e2014002. doi: 10.5620/eht.2014.29.e2014002

Conflict of Interest Statement: The authors declare that the research was conducted in the absence of any commercial or financial relationships that could be construed as a potential conflict of interest.

Copyright (๑) 2018 Zhang, Zhang, Song, Pang, Song, Cheng and Yang. This is an open-access article distributed under the terms of the Creative Commons Attribution License (CC BY). The use, distribution or reproduction in other forums is permitted, provided the original author(s) and the copyright owner(s) are credited and that the original publication in this journal is cited, in accordance with accepted academic practice. No use, distribution or reproduction is permitted which does not comply with these terms. 